\title{
SELF-IMAGE AND STUDENT TEACHING PERFORMANCE OF COED SENIORS
}

\author{
Lorna D. Capito \\ ESSU Main Campus, College of Education, Borongan City, Eastern Samar
}

Article DOI: https://doi.org/10.36713/epra9043

DOI No: 10.36713/epra9043

\begin{abstract}
The study was conducted at the Eastern Samar State University Main Campus during the second semester of the school year 2018 to 2019. It aimed to determine the self-image of the respondents in terms of their positive self-image and negative self-image. It also intended to describe their student teaching performance in terms of their average grade in Student Teaching in the Elem/Sec Schools subject; and to determine whether there is significant relationship between these variables.. Likert-type questionnaire was used to gather data as well as secondary data and employed both Descriptive and Inferential statistics for the analysis of the gathered data..

The findings of the study revealed that the respondents' perception of their level of positive self-image result to an aggregate mode of 13 which is interpreted as "high level" while their level of negative self-image resulted to an aggregate mode of 14 which is interpreted as "low level" It also reflected that 95.6\% or majority of the senior students were excellent in their teaching performance. Further results reflected that there was no significant relationship between the respondents' level of positive and negative self-image and their student teaching performance. Hence the null hypothesis was accepted.

The results of the study implied that the respondents' total level of positive subjective perception of themselves, including the image of their body and impression of their own personality and capabilities are high and that they have developed the necessary skills for teaching as reflected in their student teaching performance. These findings also imply that although the respondents' level of positive self-image is high, it does not influence their student teaching performance and outlook and preparedness towards the teaching profession.
\end{abstract}

KEYWORDS: self-image, student teaching performance

\section{INTRODUCTION}

Background of the Study

Self-image is defined as the totality of one's perception, including body image and impressions of one's personality and capabilities. According to several psychologists, self-image is comprised of a picture of one's mental capabilities, physical appearance, and the integration of experiences, desires, and feelings [1](Bailey, 2003).

Self-image can be positive and negative (PositivePsychology.com). Positive self-image contributes to selfconfidence especially in our thoughts and actions. Negative self-image, on the other hand, decreases satisfaction on areas involving physical, mental, social, emotional, and spiritual well-being. With a positive self-image, we acknowledge our potentialities while being realistic with our limitations.

The concept of self-image can be incorporated in teaching. Teachers' perception of themselves and their beliefs and perceptions of their own teaching abilities make an essential part in the practice of their profession [2](Cocca, et al., 2018). In like manner, the concept of self-image could also be useful for pre-service educators in their teaching internship.

Teaching internships provide student teachers an opportunity to experience all the responsibilities of being a teacher. Student teachers develop lesson plans and a variety of assessments that measure students' learning [3](Kelly, 2019). Previous research has revealed that teacher interns perceive Student Teaching Program positively. They consider their experiences from the program as an important and integral part for their professional life [4](Zeichner \& Gore, 1990) because they develop a better image of their duties [5] 
(McDonnough, Jacqueline \& Matkins, Juanita, 2010) and because they can build their self-confidence and selfworth [6] Bray, B.M.(2001)..

A healthy self-image is built upon a high level of self-worth [7]( Sicinski, 2008). By gaining selfconfidence and self-worth, student teachers develop a positive self-image that would help them acknowledge who they are and how they should do the best they can with what they have thus improving their performance. Hence, the conduct of this study to evaluate if there is a relationship between level of self-image and student teaching performance of COED Seniors in ESSU Main Campus.

\section{Objectives}

This investigation aims to evaluate the relationship of the level of self-image and student teaching performance of COED Seniors in ESSU Main Campus. Specifically, this study will be anchored on addressing the following objectives:

1. To determine the level of self -image of COED seniors in ESSU Main Campus in terms of their :

$$
\begin{aligned}
& \text { 1.1 Positive self-image } \\
& 1.2 \text { Negative self-image }
\end{aligned}
$$

2. To describe the student teaching performance of COED seniors in ESSU Main Campus in terms of their average grade in Student Teaching in the Elem/Sec Schools subject;

3. To determine if there is a significant relationship between the level of self-image and student teaching performance of COED seniors in ESSU Main Campus.

\section{Significance of the Study}

The results and findings of this study may provide relevant insights regarding self-image and its relevance to the students' teaching performance of COED seniors in ESSU Main Campus. This study will look forward to delivering valuable inputs to the following:

Teachers - they will get deeper understanding of the diversity of the learning of their pupils, how the self image of the students play a vital role in terms of their learning performance in their student teaching course and to take into consideration the level of self -image of their students in terms of the positive self-image and negative self-image in the teaching and learning process as well as in curriculum development.

Students - this group of individuals will be able to gain insight on how their self-image play a pivotal role in their learning performance in school, and also give them ideas on how gaining self-confidence and self-worth will develop a positive self-image that would help them acknowledge who they are and how they should do the best they can with what they have thus improving their performance as future teachers.

Parents - for them to gain significant insights on how self-image of their children affect their learning performance in school.

School Administrators- may obtain ideas from this study on how to assist the teachers improve their teaching performance and strategies as well as in curriculum development that would help them deal with the different levels of self -image of their students in terms of the positive self-image and negative self-image in the teaching and learning process as well as in curriculum development.

Future Researchers - the findings of this study may provide them vital references in similar studies and may provide essential inputs in the design and pursuit of related researches.

\section{Scope and Delimitation}

This research focused on the self-image and student teaching performance of COED Seniors in ESSU Main Campus during the School Year 2018-2019. This covered all the COED seniors both from the BEED and BSED programs taking up Student Teaching in Elementary/Secondary Schools subject.

\section{METHODOLOGY}

\section{Research Design}

The research design that the researcher used was descriptive- correlational design. Initially, descriptive approach through survey was employed to gather the pertinent data relevant to the study. A survey is a descriptive type of research design used when the researcher intends to provide a quantitative or numeric description of trends, attitudes, opinions of a population by studying a sample of that population [8](Cresswell, J.W., 2009). The researcher gathered information through survey the level of self-image of the respondents and through secondary data their student teaching performance in terms of their average grade in Student Teaching in the Elem/Sec Schools subject. This study then used the correlational design to examine if there is a significant relationship between the level of self-image and student teaching performance of COED seniors in ESSU Main Campus. 


\section{Locale of the Study}

The study was conducted in Eastern Samar State University, College of Education. COED Seniors who were officially enrolled in the Student Teaching in the Elem/Sec Schools subject of both the BEED and BSED programs were involved in the study.

\section{Respondents of the Study}

The respondents of the study were composed of 160 graduating students of SY 2018-2019 of both the BEED and BSED programs. The respondents must satisfy the following criteria for inclusion: (1) Must be officially enrolled in student teaching course and (2) Must be a graduating student.

\section{Sampling Procedure}

Total enumeration was employed in identifying the respondents. Overall, this study had 160 respondents composed of 61 BSED and 99 BEED senior students. The study included all COED students deployed for practice teaching for School Year 2018 - 2019.

\section{Research Instrument}

The research instrument of the study was a researcher-modified one. Some parts of the instrument were adapted from the study of [9]Iglesia and Araneta (2015). The self-image questionnaire was modified by adding the first part to gather the profile variable of the respondents. Hence, Part 1 contains the profile of the COED seniors. Part II asks about the students' self-assessment on what positive and negative qualities do they project in their behavior and relationships. The questionnaire which the respondents were required to complete after their permission was composed of 30 items on a 2-point scale with the range as follows: $1=$ if occasionally true and $0=$ if never true.

A test for validity and reliability was run to check for consistency of measures used in the research instrument.

\section{Data Gathering Procedure}

Upon the approval of the respondents, the questionnaires were administered by means of an assisted interview. The researcher personally interviewed the respondents.

\section{Data Analysis}

The researcher employed both Descriptive and Inferential statistics for the analysis of the gathered data. Identification of frequencies and measure of central tendency such as the mode was used.

The inferential aspect of data analysis made use of person product moment correlation for continuous data and Spearman's rank order correlation for the variables in categorical nature.

\section{RESULTS AND DISCUSSION}

The results of the study are discussed below in accordance with the sequence of the objectives stated in this study.

Table I below shows the level of self-image of COED seniors in ESSU Main Campus in terms of their positive self-image and negative self-image. In terms of the reported positive self-image of the COED seniors, result shows an aggregate mode of 13 which is interpreted as "high level". This means that senior students project more positive qualities than negative qualities indicative of positive self-image and high self-esteem. This implies that the teacher education senior students perceived themselves as having a healthy self-image having a high level of positive self-image. This only describes that the perception of themselves and their beliefs as well as of their teaching abilities is high.

Table 1. Level of Self-Image of COED Seniors

\begin{tabular}{lcl}
\hline $\begin{array}{l}\text { Reported } \\
\text { Self-Image }\end{array}$ & Aggregate Mode & Interpretation \\
\hline Positive Self-Image & 13 & High Level \\
Negative Self-Image & 14 & Low Level \\
\hline
\end{tabular}

In terms of the senior students' perception of their negative self-image, result shows an aggregate mode of 14 which is interpreted as "low level" as shown in Table 1 above. This implies that they possess a low level of negative qualities indicative of a high or positive image. This only describes that the teacher education senior 
students do not have low level of positive self-image and that their perception of themselves and their beliefs as well as of their teaching abilities is not low.

Table 2 below presents the teaching performance of COED seniors. It reflects that $93.45 \%$ or majority of the senior students were excellent in their teaching performance. Only a meagre $3.3 \%$ got a rating of outstanding and another $3.3 \%$ have a rating of very good. From the result, it can be inferred that COED student teachers have developed the necessary skills for teaching and can excellently practice the techniques, skills, and positive attitudes in teaching in preparation for the real world of teaching profession as reflected in their student teaching performance.

Table 2 Student Teaching Performance of COED Seniors

\begin{tabular}{llll}
\hline $\begin{array}{l}\text { Final Grade } \\
\text { In Student Teaching }\end{array}$ & Adjectival Rating & Frequency & Percentage \\
\hline 1.0 & Outstanding & 2 & 1.2 \\
$1.1-1.5$ & Excellent & 153 & 95.6 \\
$1.6-2.0$ & Very Good & 5 & 3.1 \\
& Total & 160 & $100 \%$ \\
\hline
\end{tabular}

From the result shown in table 2 above, it can be inferred that COED student teachers have developed the necessary skills for teaching and can excellently practice the techniques, skills, and positive attitudes in teaching in preparation for the real world of teaching profession as reflected in their student teaching performance.

The result of the study on the relationship between the self-image of COED seniors and their student teaching performance is reflected on Table 3 below.

Table 3. Relationship Between Level of Self-Image and Student Teaching Performance of COED Seniors

\begin{tabular}{|c|c|c|c|c|}
\hline \multirow[t]{2}{*}{$\begin{array}{l}\text { Reported } \\
\text { Self-Image }\end{array}$} & \multicolumn{4}{|c|}{ Teaching Performance (GWA) } \\
\hline & Measure & Interpretation & p-value & Interpretation \\
\hline $\begin{array}{l}\text { Positive } \\
\text { Self-Image }\end{array}$ & $r=.220$ & $\begin{array}{l}\text { Low } \\
\text { Correlation }\end{array}$ & .636 & Not Significant \\
\hline $\begin{array}{l}\text { Negative } \\
\text { Self-Image }\end{array}$ & $r=-.176$ & $\begin{array}{l}\text { Negligible } \\
\text { Correlation }\end{array}$ & .423 & Not Significant \\
\hline
\end{tabular}

*tested at 0.05 level of significance, two-tailed

To explore the relationship between the reported self-image of the respondents and their teaching performance, Pearson's Product Moment Correlation was run. The results shows a positive, low correlation between the Positive Self-Image and the Teaching

Performance of the BEED Senior students of ESSU that was statistically not significant $(r=.220, p=.636)$. The association between the Negative Self-Image and the Teaching Performance of the respondents revealed as negative, negligible correlation which was likewise not statistically significant, $(r=-.176, p=.141)$. It is therefore proven that the self-image of COED seniors during the school year 2018-2019 in terms of positive andnegative image are not significantly related to their student teaching performance. This result therefore rejects the null hypothesis that there is no significant relationship between the respondents' level of positive and negative self-image and their student teaching performance. These findings imply that the teacher education seniors' perception of themselves, including the image of their body and impression of their own personality and capabilities does not influence their outlook and preparedness towards the teaching profession . These results support the findings of [10]Aryana (2010) that the low correlation between self-image and school performance does not indicate that high self-image leads to good performance. Instead, high self-image is partly the result of good school performance. 


\section{CONCLUSION}

From the results of the study, it can be concluded that:

1. The self-image of COED Seniors in terms of their positive self-image is "high level".

This means that senior students project more positive qualities than negative qualities indicative of positive selfimage and high self-esteem. In terms of the senior students' perception of their negative self-image, result shows an aggregate mode of 14 which is interpreted as "low level". This implies that they possess a low level of negative qualities indicative of a high or positive image.

2. The student teaching performance of the respondents in terms of their average grade in Student Teaching subject is "excellent". They have developed the necessary skills for teaching and can excellently practice the techniques, skills, and positive attitudes in teaching in preparation for the real world of teaching profession.

3. The self-image of COED seniors during the school year 2018-2019 in terms of their positive and negative self-image is not significantly related to their student teaching performance. These findings imply that the teacher education seniors' perception of themselves, including the image of their body and impression of their own personality, and capabilities does not influence their outlook and preparedness towards the teaching profession.

\section{REFERENCES}

1. Bailey, Joseph A. (2003).Self-image. Self-concept, and self-identity revisited. Journal of the National Medical Association. $2^{\text {nd }}$ May, 5(5); 383-386

2. Cocca, Michaela et al.( 2018). Correlation between Self-Efficacy Perception and Teaching Performance : The Case of Mexican Preschool and Primary SchoolTeachers. Arab World English Journal AWE. Volume 9.Number 1.March 2018.

3. Kelly, Angela (2003).Self-Image : "Personal is Political" in Camerawork. williamwolff.org

4. Zeichner \& Gore (1990). Action Research and Reflective Teaching in Pre-ServiceTeacher Education: A Case Study From the United States. Teaching and Teacher Education. Vol 7. No 2. pp. 119-136. 1991

5. Mcdonnough, Jacqueline \& Matkins, Juanita. (2010). The Role of Field Experience in Elementary Preservice Teachers' Self-Efficacy and Ability to Connect Research to Practice. School Science and Mathematics.110.1323.10.1111/j.1949 8594.2009.00003.x.

6. Bray, B.M.(2001) The Influence of Academic Achievement on a College Stuedents Self-Esteem. Missouri Western State University, Saint Joseph, MO.

7. Sicinski (2008). What Exactly Is A Self-Image? Here's What You Need to Know.Iqmatrix.com.

8. Cresswell, J. (2009). Research Design : Qualitative, Quantitative, and Mixed-Method Approaches. 3rd Edition: Sage Publications. University of Michigan

9. Iglesia and Araneta (2015) Self-Image and Student Learning Performance .Retrieved from http://self-image student learning performance of practicumers in WMSU main campus and external studies.com.ph//

1. 10.Aryana, M. (2010).Relationship between self-esteem and academic achievement amongst pre-university students. Journal of Applied Sciences, 10, 2474-2477. http://dx.doi.org/10.3923/jas.2010.244.2477. 